Nevşehir Bilim ve Teknoloji Dergisi Cilt 5(2) 65-73 2016

DOI: 10.17100/nevbiltek.284731

URL: http://dx.doi.org/10.17100/nevbiltek.284731

\title{
Special Education Teachers’ Knowledge about Genetic Disorders
}

\author{
Serkan Yılmaz ${ }^{1, *}$, Aynur Bütün Ayhan², Bayram Göktaş ${ }^{3}$ Utku Beyazıt ${ }^{4}$ \\ ${ }^{1}$ Ankara Üniversitesi Să̆lık Bilimleri Fakültesi Ebelik Bölümü 06340 Ankara/Türkiye \\ ${ }^{2}$ Ankara Üniversitesi Sağlık Bilimleri Fakültesi, Çocuk Gelişimi Bölümü 06340 Ankara/Türkiye \\ ${ }^{3}$ Ankara Üniversitesi Sağllk Bilimleri Fakültesi, Sağlık Yönetimi Bölümü 06340 Ankara/Türkiye \\ ${ }^{4}$ YakınDoğu University, Fen-Edebiyat Fakültesi, Psikoloji Bölümü, 99138 Lefkoşa/Kuzey Kıbrıs Türk \\ Cumhuriyeti
}

\begin{abstract}
The purpose of this work is to determine the knowledge level of the special education teachers about genetic disorders. A total of 83 teachers' from working on special education centers were used. Knowledge of cell division was the highest among participants (33.7\%). However, majority of the participants specified that they had no information about genetic counselling (80.7\%), prenatal genetic diagnosis (79.5\%), polygenic inheritance (72.3\%), mitochondrial inheritance (71.1\%), autosomal dominant and recessive genes (65.1\% and 63,9\% respectively). The majority of the participants were mostly aware of Down syndrome (69.9\%) followed by Rh factor (31.3\%), diabetes (27.7\%), muscular dystrophy (24.1\%) and albinism (24.1\%). Our results showed that the majority of respondents were lack of adequately enough genetic knowledge.
\end{abstract}

Keywords: Genetic disorders, counselling, knowledge, teachers, special education

\section{Genetik Hastalıklar Konusunda Özel Eğitim Öğretmenlerinin Bilgi Düzeyleri}

Öz

$\mathrm{Bu}$ çalı̧̧manın amacı özel eğitim öğretmenlerinin genetik hastalıklar konusunda bilgi düzeylerinin belirlenmesidir. Total olarak 83 özel eğitimde çalışan öğretmen çalışmaya dahil edilmiştir. Hücre bölünmesi katılımcılar arasında en fazla bilinen bilgi olarak tespit edilmiştir (33.7\%). Bununla birlikte katılımcıların çoğu genetik danışmanlık (80.7\%), prenatal genetik tanı (79.5\%), polygenic kalıtım (72.3\%), mitokondriyal kalitım (71.1\%), otozomal dominant and resesif genler (65.1\% and 63,9\% respectively) konusunda bilgilerinin olmadığını belirtmişlerdir. Katılımcıların büyük çoğunluğu Down sendromu (69.9\%) Rh faktörü (31.3\%), diabet (27.7\%), kas distrofisi (24.1\%) ve albinizm (24.1\%) konularında bilgiye sahip olduklarını belirtmişlerdir. Sonuçlarımız katılımcıların büyük bir çoğunluğunun yeterli genetik bilgiye sahip olmadıklarını göstermiştir.

Anahtar Kelimeler: Genetik hastalıklar, danışma, bilgi, öğretmenler, özel eğitim

*e-mail: serkanyilmaz@ankara.edu.tr 


\section{Introduction}

The first years of man are the basis of his or her future. Psychologists, educators, speech and language therapists and others, have recently recognized the critical importance of early years.Therefore, they have been also recently paying great attention to providing early education or intervention [1]. Special education is defined as training aimed at meeting the educational needs of individuals who need special training in an environment that suits the shortcomings and characteristics of persons, using specially developed training programs and techniques provided by specially trained personnel [2]. It is emphasized that children who have special education differs from the average child to the extent that he or she needs special educational services to reach full potential. The main categories of exceptionality are children with major categories, mental differences, communication differences, learning difficulties, sensory differences, behavioral differences, multiple and severely disabling, physical and health differences, attention deficit hyperactivity disorder and autism [3]. According to the world Health Report of WHO [4], about $15 \%$ of the world's population lives with some form of disability, of whom 2-4\% experience significant difficulties in functioning [4].

Special education in Turkey is carried out through legal regulations [1]. It is stated that there are 4 million exceptional children between 0 and 18 years old, in Turkey. In 1999, it was stated that only 3\% of the exceptional students could benefit from special education. According to the Turkey Disability Study, $12.29 \%$ of the population was comprised of people with special needs in 2002 [5]. Since 2002, the Ministry of National Education has requested special training from 212 Guidance and Research Centers throughout Turkey. These centers are government institutions responsible for the educational evaluation of students for special education eligibility. Once a student is identified with special needs, these centers are responsible for placing the student in an appropriate educational environment and following up all the educational information about the student [6].

It is stressed out that each year, the number of identified children requiring special education services increases. However, the number of qualified teachers available to serve the needs does not improve [7] Teachers argued to represent the most fundamental components of special education and inclusion, since they are mainly responsible for individualized education programs [5]. It is stated that special educators' knowledge in content, pedagogy, inquiry, curriculum, and educational settings must be developed. Providing special educators with a deep understanding in these areas is argued to allow them to be confident in their decisions as they begin their teaching careers. This confidence will help to not only retain teachers in the field but will also guide them in their ability to provide effective instruction for all people [8]. It is stressed out that special educators need an understanding of how disability presents itself in a variety of aspects such as genetics and neuropsychology as recently research on disabilities has grown in volume and sophistication. It is claimed that researchers and special educators provide more evidence about how the brain works and how it works, how brain function affects the computing capacity of some students with disabilities and how the brain can intervene to improve the information processing capacity [9]. Science is argued to be an important partner of the field of special education. It is stated that special educators use science to approve or reject the identification and teaching approaches of students with disabilities. It is also stated that current research and implementation use know-how to find better 
approaches to prevention of disability, and reduced number of children referred for special education [10].

The Special Education Services Regulation is defined as the training of special needs students with their peers in a special training environment without special needs. Students can attend full-time or part-time. Special education regulations require schools to develop an Individualized Education Program for each student with special needs, regardless of being educated in inclusive settings or not [6]. Furthermore, there are residential schools for children with visual impairments, hearing impairments, and orthopaedic impairments at both the elementary and secondary levels. Private special education and rehabilitation centers are widespread in Turkey. Therefore, students with disabilities can receive education one on one or in small groups and, rehabilitation or therapy services in those centers [11].

Genetics is argued to be one of the most exciting areas in which new knowledge is increasing our understanding of human development. It is stated that special educators have moved from a medical model, which stresses that the physical condition exists within the child, to an ecological model, which focuses on the individual's interaction with the environment. However, genetics research suggests that environmental changes can activate previously inactive genes, creating new heredity-environment interactions and affecting behavior [12 and 3].

For these reasons we decided to analyze the level of the knowledge of special education teachers about genetically inherited diseases since they educate disabled people.

\section{Material and Methods}

A descriptive cross-sectional study was used to achieve the aim of this work. A total of 83 teachers' were used to determine the knowledge level of basic genetic information and genetic diseases. The questionnaire was developed after an extensive review of the literature and distributed to all educators. The questionnaire divided into three distinct sections. In the first section, respondents were asked for demographic information, including information about their work settings. The second section was designed to test basic knowledge of genetic concepts and the last section was designed to test knowledge of genetic diseases. Each item was evaluated individually according to the frequency of responses. Demographic data was developed to determine demographic variables including age, gender, level of education, years of experience, whether they received any training in the area of genetics.

Data were analyzed using the Statistical Package Program (version 17.0; SPSS Inc., Chicago, IL). Descriptive statistics, including mean \pm standard deviation, frequencies, and percentages were calculated. To determine the relationship between two categorical variables, the Mann-Whitney U test was used and Kruskal-Wallis test was used for more than two groups. The statistical significance was set at the $5 \%$ level $(P \leq 0.05)$.

\section{Results}

\section{Demographic data}

The demographic information of the participants is shown in table 1. The age of the participants ranged between 20 and 45 . The majority (69.9\%) of respondents was women. Average time of working as a teacher was 6.36 (ranged between 1 and 20 years). 
Yılmaz S., Bütün-Ayhan A., Göktaş B., Beyazıt U.

Table 1. Socio-Demographic Variables of Research Group

\begin{tabular}{|c|c|c|c|}
\hline & & Frequency & Percentage \\
\hline \multirow{2}{*}{ Gender } & Woman & 58 & 69,9 \\
\hline & Male & 25 & 30,1 \\
\hline \multirow{4}{*}{ Age } & $\leq 25$ Years Old & 29 & 34,9 \\
\hline & 26-30 Years & 13 & 15,7 \\
\hline & 31-35 Years & 15 & 18,1 \\
\hline & $\geq 36$ Years Later & 26 & 31,3 \\
\hline \multirow{3}{*}{ Professional Experience } & $\leq 5$ Years And Under & 44 & 53,0 \\
\hline & 6-10 Years & 14 & 16,9 \\
\hline & $\geq 11$ Years And Over & 25 & 30,1 \\
\hline \multirow{3}{*}{ Working Time In Special Education } & $\leq 5$ Years And Under & 53 & 63,9 \\
\hline & 6-10 Years & 22 & 26,5 \\
\hline & $\geq 11$ Years And Over & 8 & 9,6 \\
\hline \multirow{2}{*}{ Taking Genetic Courses During Graduate } & Yes & 46 & 55,4 \\
\hline & No & 37 & 44,6 \\
\hline \multirow{4}{*}{ Source of Genetic Information } & Education & 38 & 56,7 \\
\hline & Research & 12 & 17,9 \\
\hline & Education-Research & 12 & 17,9 \\
\hline & $\begin{array}{l}\text { Other (Environmental, Pharmaceutical } \\
\text { Companies, Etc) }\end{array}$ & 5 & 7,5 \\
\hline
\end{tabular}

The majority (55 \%) of participants learned genetics during their degree programme. However, remains were learned genetic from other sources such as certified education, research, social media etc. The $71.1 \%$ of the participants give training people with Down syndrome (Table 2).

\begin{tabular}{|c|c|c|c|c|c|c|c|}
\hline \multirow{5}{*}{$\begin{array}{l}\text { Knowledge of } \\
\text { pasic genetic issues }\end{array}$} & Source of Genetic Information & $\mathrm{N}$ & Median & Minimum & Maximum & $\mathrm{KWX}^{2}$ & $\mathrm{p}$ \\
\hline & Education & 38 & 8,0000 &, 00 & 20,00 & \multirow{4}{*}{5,224} & \multirow{4}{*}{0,156} \\
\hline & Research & 12 & 4,0000 & 1,00 & 14,00 & & \\
\hline & Education-Research & 12 & 9,5000 & ,00 & 23,00 & & \\
\hline & $\begin{array}{l}\text { Other (Environmental, } \\
\text { Pharmaceutical Companies, etc) }\end{array}$ & 5 & 2,0000 & ,00 & 14,00 & & \\
\hline \multirow{4}{*}{$\begin{array}{l}\text { Knowledge of } \\
\text { Genetic Diseases }\end{array}$} & Education & 38 & 11,0000 &, 00 & 32,00 & \multirow{4}{*}{9,920} & \multirow{4}{*}{,019 } \\
\hline & Research & 12 & 5,0000 & 1,00 & 15,00 & & \\
\hline & Education-Research & 12 & 14,0000 & 1,00 & 38,00 & & \\
\hline & $\begin{array}{l}\text { Other (Environmental, } \\
\text { Pharmaceutical Companies, etc) }\end{array}$ & 5 & 5,0000 &, 00 & 12,00 & & \\
\hline
\end{tabular}

\section{Basic Knowledge of Genetics}

The knowledge questions are shown in table 3. Knowledge of the cell division was the highest among participants (33.7\%). However, majority of the participants specified that they had no information about genetic counseling $(n=67,80.7 \%)$, prenatal genetic diagnosis $(n=66,79.5 \%)$, polygenic inheritance ( $n=60,72.3 \%)$, mitochondrial inheritance $(n=59,71.1 \%)$, autosomal dominant and recessive genes $(n=54$, 65.1\% and 53, 63,9\% respectively). There was no statistical difference about the basic genetic information between male and female participants (Table 4). There were no statistical differences between the knowledge level and working year. 
Table 3. The Distribution of Knowledge Level about Basic Genetics Issues among Research Group

\begin{tabular}{|c|c|c|c|c|c|c|}
\hline & \multicolumn{2}{|c|}{ I have no Information } & \multicolumn{2}{|c|}{$\begin{array}{l}\text { I have some } \\
\text { information }\end{array}$} & \multicolumn{2}{|c|}{$\begin{array}{l}\text { I have enough } \\
\text { Information }\end{array}$} \\
\hline & Frequency & Percent & Frequency & Percent & Frequency & Percent \\
\hline Cell Division & 18 & 21,7 & 37 & 44,6 & 28 & 33,7 \\
\hline Mendelian Inheritance & 33 & 39,8 & 30 & 36,1 & 20 & 24,1 \\
\hline Polygenic Inheritance & 60 & 72,3 & 21 & 25,3 & 2 & 2,4 \\
\hline X-Linked Genetic Diseases & 25 & 30,1 & 46 & 55,4 & 12 & 14,5 \\
\hline Y-Linked Genetic Diseases & 27 & 32,5 & 46 & 55,4 & 10 & 12,0 \\
\hline Autosomal Recessive Genetic Diseases & 53 & 63,9 & 22 & 26,5 & 8 & 9,6 \\
\hline Autosomal Dominant Genetic Diseases & 54 & 65,1 & 21 & 25,3 & 8 & 9,6 \\
\hline Mitochondrial Inheritance & 59 & 71,1 & 21 & 25,3 & 3 & 3,6 \\
\hline The Genetic Code, Protein Synthesis & 46 & 55,4 & 30 & 36,1 & 7 & 8,4 \\
\hline Genetics And Ethics & 41 & 49,4 & 38 & 45,8 & 4 & 4,8 \\
\hline Prenatal Genetic Diagnosis & 66 & 79,5 & 14 & 16,9 & 3 & 3,6 \\
\hline Genetic Counseling & 67 & 80,7 & 13 & 15,7 & 3 & 3,6 \\
\hline
\end{tabular}

Knowledge about Genetic Diseases

The results of this work showed that the majority of the participants were mostly aware of Down syndrome (69.9\%, $\mathrm{n}=58$ ) followed by Rh factor (31.3\%), diabetes (27.7\%), muscular dystrophy (24.1\%) and albinism (24.1\%).

Table 4. The Distribution of Level of Knowledge about Genetic Diseases

\begin{tabular}{|c|c|c|c|c|c|c|}
\hline & \multicolumn{2}{|c|}{$\begin{array}{c}\text { I have } \\
\text { no Information }\end{array}$} & \multicolumn{2}{|c|}{$\begin{array}{c}\text { I have } \\
\text { some information }\end{array}$} & \multicolumn{2}{|c|}{$\begin{array}{c}\text { I have } \\
\text { enough Information }\end{array}$} \\
\hline & Frequency & Percent & Frequency & Percent & Frequency & Percent \\
\hline Phenylketonuria & 67 & 80,7 & 15 & 18,1 & 1 & 1,2 \\
\hline Rh Factor & 27 & 32,5 & 30 & 36,1 & 26 & 31,3 \\
\hline Diabetes Mellitus & 46 & 55,4 & 14 & 16,9 & 23 & 27,7 \\
\hline Thalassemia & 66 & 79,5 & 10 & 12,0 & 7 & 8,4 \\
\hline Sickle Cell Anemia & 57 & 68,7 & 16 & 19,3 & 10 & 12,0 \\
\hline Hemophilia A And B & 32 & 38,6 & 37 & 44,6 & 14 & 16,9 \\
\hline Down Syndrome & 6 & 7,2 & 19 & 22,9 & 58 & 69,9 \\
\hline Spina Bifida / Anencephaly & 45 & 54,2 & 19 & 22,9 & 19 & 22,9 \\
\hline Cystic Fibrosis & 57 & 68,7 & 14 & 16,9 & 12 & 14,5 \\
\hline Turner Syndrome & 49 & 59,0 & 20 & 24,1 & 14 & 16,9 \\
\hline Muscular Dystrophy & 47 & 56,6 & 16 & 19,3 & 20 & 24,1 \\
\hline Albinism & 35 & 42,2 & 28 & 33,7 & 20 & 24,1 \\
\hline Polydactyly & 72 & 86,7 & 7 & 8,4 & 4 & 4,8 \\
\hline Galactosemia & 65 & 78,3 & 13 & 15,7 & 5 & 6,0 \\
\hline Brachydactyly & 74 & 89,2 & 8 & 9,6 & 1 & 1,2 \\
\hline Klinefelter's Syndrome & 64 & 77,1 & 13 & 15,7 & 6 & 7,2 \\
\hline Cri Du Chat Syndrome & 69 & 83,1 & 6 & 7,2 & 8 & 9,6 \\
\hline Edwards Syndrome & 61 & 73,5 & 16 & 19,3 & 6 & 7,2 \\
\hline Patau Syndrome & 72 & 86,7 & 7 & 8,4 & 4 & 4,8 \\
\hline Xeroderma Pigmentosum & 73 & 88,0 & 8 & 9,6 & 2 & 2,4 \\
\hline Achondroplasia & 74 & 89,2 & 6 & 7,2 & 3 & 3,6 \\
\hline
\end{tabular}

Statistical analysis showed us that women had more knowledge than males in view of genetic disorders (Table 5). There were no statistical differences between the knowledge level and working year. Education degree and research were more important source for genetic diseases knowledge among participants $(\mathrm{p}<0.05)$ 
Yılmaz S., Bütün-Ayhan A., Göktaş B., Beyazıt U.

Table 5. Basic Genetic Issues and Genetic Diseases among Research Group According to Gender, Working Duration and Education

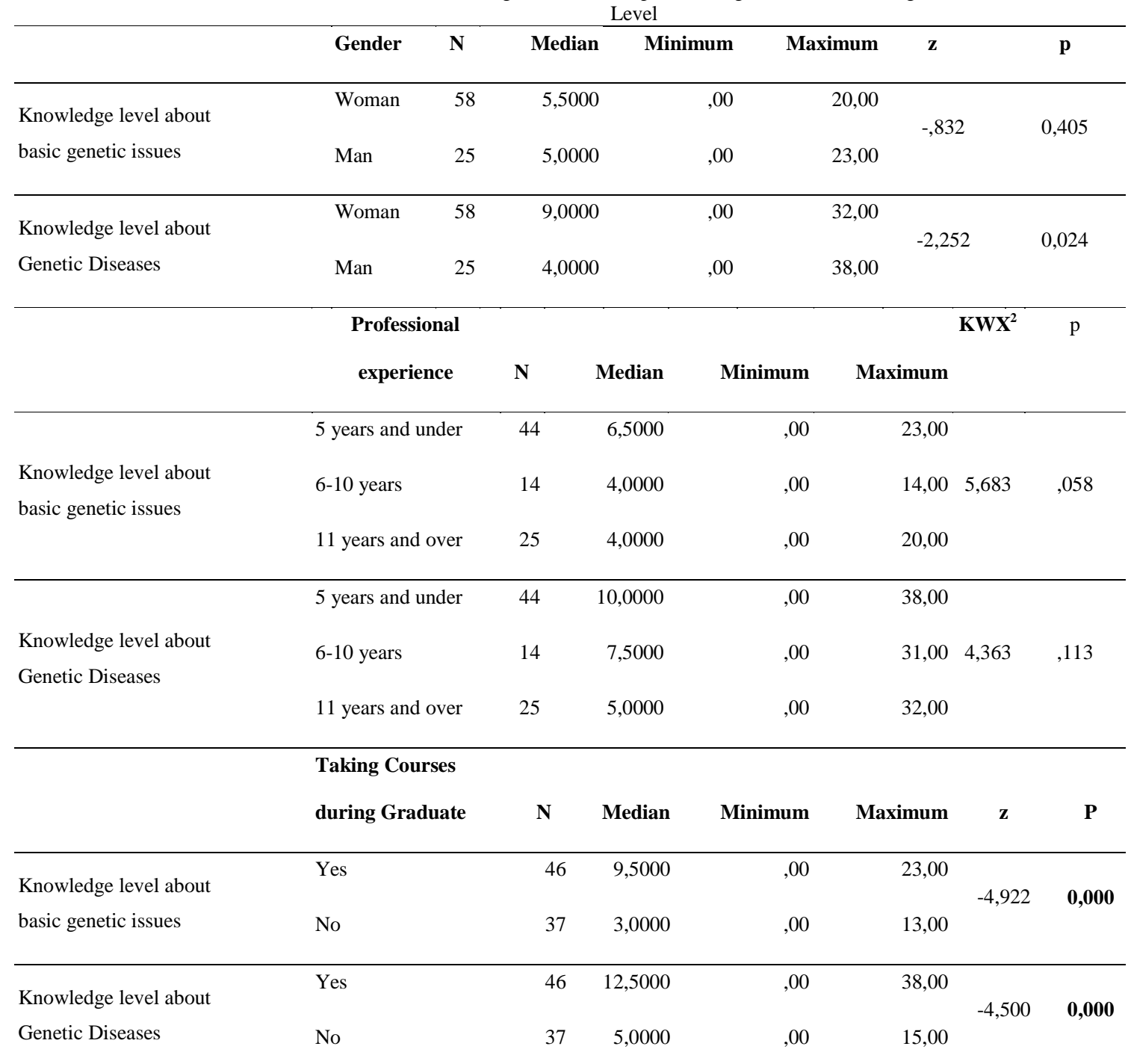

\section{Discussion}

Special education is specially designed support for students who are mentally, physically, socially and emotionally delayed. And we know that genetic background is very important for development of these skills. Increasing numbers of health care users are argued to confront with new genetic knowledge and discoveries that offer new types of medical decision making [13]. Genetic information is suggested to contribute to individual and general prevention [14]. It is claimed that parents show a surprising degree of interest in predictive testing of children, even when there are no preventive interventions available and many persons report themselves ready to alter their lifestyles and plans for marriage and family in response to test results [15 and 16]. Virtually all human traits are stated to have genetic and environmental components. Advances in genetics research during the past 20 years have given researchers a better understanding of genes and the effects of the genes on brain structure and function, and the role of genetics in communication development and disorders. It is argued that professionals should remember that virtually all traits are influenced by both genetics and environment and within the area of clinical and education services, experts should use their knowledge about genetics in assessment, treatment, and collaboration [17]. However, many studies indicate that experts lack an 
understanding of the role of genetics. Bankhead et al [18] showed that $96.0 \%$ of practice nurses had significant confident dealing with patient concerns about familiar breast cancer than colorectal cancer. Young Kim [19] reported that nurses need for genetic content in nursing curriculum. And their knowledge largely came from the mass media. The nurses also expressed great interest in educating and counseling patients. Overall, the survey found a positive correlation between the nurses' level of knowledge and their degree of interest in genetics. Bottorff et al. [20] studied the educational needs and professional roles of Canadian physicians and nurses, and they reported that $48 \%$ of physicians and $31 \%$ of nurses lacked formal education in genetics. In a study conducted by Tomatır et al. [21], primary care nurses' knowledge about genetics and genetic counseling, and the educational needs of nurses related to human genetics was examined. It was found out that a high percentage of nurses admitted they had insufficient knowledge about the genetic basis of diseases. Spruill et al. [22] reported that 56\% AfricanAmerican nurses described their knowledge of genetic nursing as fair or poor, $43 \%$ as good. $60 \%$ reported that they had never had a course in genetic nursing. 86\% responded that they knew how and 85\% had completed a family health history. In another study conducted by Salm et al. [23] neurologists' and psychiatrists' knowledge, attitudes, and practices concerning genetics was examined. It was found out that most respondents thought that genetic tests should be performed more frequently, but almost half believed genetic tests could harm patients psychologically and considered legal protections inadequate. Almost half of neurologists and over $75 \%$ of psychiatrists did not have a genetics professional to whom to refer patients.

Apart from the experts, it is suggested that, most members of the public do not know basic aspects of genetics (e.g., that genes in fact reside in every cell in the body. In addition, patients have been found to misunderstand several aspects of the role of genetics. In a study, 64 individuals who had or were at risk for genetic diseases were interviewed. It was found out that the participants had various misunderstandings that can affect coping, and testing, treatment and reproductive decisions. It was also found out that many believed they could control genetic disorders [24]. In a questionnaire study involving a total of 111 patients and their relatives, the level information about genetics was examined. The findings demonstrated that a general lack of genetic insight amongst the study subjects. There was no significant correlation between genetic knowledge and age, level of education, disease duration or severity [25]. In another study, a postal survey administered to 560 women who had been offered prenatal screening and knowledge about, and attitudes toward, genetic testing and the uses of genetic information was examined. Respondents strongly supported the use of genetic information to improve disease diagnosis and to help understand disease causes; however, people also held a more critical attitude towards certain aspects of testing and genetic information [13].

In conclusion our results showed that the majority of respondents were lack of adequately enough genetic knowledge. We conclude therefore that it is essential to ensure that educational provision for special education teachers' include not only the genetic concepts, but also how these are applied to special education.

\section{Acknowledgement}

The authors thanks to Arif Babacan for his support during collection of the data. 
[1] Sabuncuoglu, M., Diken, İ. (2010) Early childhood intervention in Turkey: Current situation, challenges and suggestions, International Journal of Early Childhood Special Education 2(2), 149-160.

[2] Cavkaytar, A. (2006) Teacher training on special education in Turkey. The Turkish Online Journal of Educational Technology 5(3), 41-45.

[3] Galagher, K., Anastasiow, A. (2009) Educating Exceptional Children. U.S.A.: Cangagae Learning.

[4] World Health Organization (2011) World Report On Disability. Switzerland: WHO Press.

[5] Leana-Taşcılar, M. (2014) The contribution of education to the special education qualifications and needs of teacher candidates. Hasan Ali Yücel Eğitim Fakültesi Dergisi, 11(22), 135-155

[6] Çakıroğlu, O., Melekoğlu, M.M. (2014) Statistical trends and developments within inclusive education in Turkey. International Journal of Inclusive Education 18(8), 798-808. doi: 10.1080/13603116.2013.836573

[7] Olivarez, M.S., Arnold, M. (2011) Personal and demographic characteristics of retained teachers of special education. Education 126(4), 702-710.

[8] Morewood, A., Condo, A. (2012) A preservice special education teacher's construction of knowledge: Implications for coursework and retention in the field. Rural Special Education Quarterly 31(1), 15-21

[9] Bronwell, M., Sindelar, P.T., Kiely, M.T. (2010) Special education teacher quality and preparation: Exposing Foundation, Constructing a New Model. Council for Exceptional Children, 76(3), 357-377. doi: 10.1177/001440291007600307.

[10] Chard, D. J. (2004) Maintaining the relationship between science and special education. Journal of Learning Disabilities, 37(3), 213-217. doi: 10.1177/00222194040370030501

[11] Melekoglu, M. M. (2014) Characteristics of inclusive classrooms in Turkey. Journal of the International Association of Special Education 15(2), 24-30.

[12] Hernandez, L.M., Blazer, D.G. (2006) Genes, behavior, and the social environment: Moving beyond the nature/nurture debate. Washington, D.C.: The National Academies Press.

[13] Etchegary, H., Cappelli, M., Potter, B., et al. (2010) Attitude and Knowledge about genetics and genetic testing. Public Health Genom. 13, 80-88. doi: 10.1159/000220034.

[14] Sachs, L. (1999) Knowledge of no return getting and gi6ing information about genetic risk Acta Oncologia 38(6), 735-740.

[15] Lawrence, R.E., Appelbaum, P.S. (2011) Genetic testing in psychiatry: A review of attitudes and beliefs. Psychiatry, 74(4), 315-331. doi: 10.1521/psyc.2011.74.4.315

[16] Houfek, J.F., Soltis-Vaughan, B.S., Atwood, J., et al (2015) Adults' perceptions of genetic counseling and genetic testing. Applied Nursing Research 28, 25-30. doi: 10.1016/j.apnr.2014.03.001 
[17] Garrett, J.W. (2012) Understanding and applying genetics knowledge in the schools. Perspectives on School-Based Issues, 16, 27-31. doi:10.1044/sbi13.2.27

[18] Bankhead, C., Emery, J., Qureshi, N., et al. (2001) New developments in genetics-knowledge, attitudes and information needs of practice nurses. Family Practice 18, 475-486. doi: 10.1093/fampra/18.5.475

[19] Young Kim, M. (2003) The Nurses' Knowledge and Perception of Their Role in Genetics. Journal of Korean Academy of Nursing 33, 1083-1092.

[20] Bottorff, J.L., Blaine, S., Carroll, J.C., et al. (2005) The educational Needs and Professional Roles of Canadian Physicians and Nurses regarding Genetic Testing and Adult Onset Hereditary Disease. Community Genetics 2005; 8(2): 80-87. doi:10.1159/000084775

[21] Tomatır, A.G., Sorkun, H.Ç., Demirhan, H., et al. (2006) Nurses' professed knowledge of genetics and genetic counseling. Jornal of Experimental Medicine 210, 321-332 doi:10.1620/tjem.210.321.

[22] Spruill, I., Coleman, B., Collins, J. (2009) Knowledge, Belief and Practices of African-American Nurses Regarding Genetics/Genomics. Journal of National Black Nurses’ Association 20(2), 2024.

[23] Salm, M., Abbate, K., Appelbaum, P., et al. (2014) Use of genetic tests among neurologists and psychiatrists: Knowledge, attitudes, behaviors, and needs for training. Journal of Genetic Counseling 23, 156-163. doi: 10.1007/s10897-013-9624-0

[24] Klitzman, R.L. (2010) Mis-understandings concerning genetics among patients confronting genetic disease. Journal of Genetic Counseling 19, 430-446. doi: 10.1007/s10897-010-9307-z.

[25] Prakasha, K.M., Luma, S.Y., Tan, E.K. (2006) Knowledge about the genetics of essential tremor in patients and their relatives. European Journal of Neurology 2006; 13: 1266-1269. doi: 10.1111/j.1468-1331.2006.01517.x 